\title{
Management of abnormal cytology results and correlation of cytopathologic results accompanied by colposcopy in our clinic
}

\author{
Kliniğimizdeki anormal servikal smear sonuçlarının yönetimi ve kolposkopi eşliğinde alınan \\ sitopatoloji sonuçlarının korelasyonu
}

\section{Ozan Dogan ${ }^{1}$, Ahmet Yildiz ${ }^{2}$, Cigdem Pulatoglu ${ }^{3}$}

\begin{abstract}
Aim: Pap smear test is a major screening test for early diagnosis and treatment of cervix cancer. The aim of our study was to assess the value of colposcopy and histopathologic examination in the management of patients with abnormal cervical cytology by Bethesda Classification.

Methods: In this study, we aimed to compare and evaluate the diagnosis of 12,381 cytology material examined in our gynecology clinic during the years between 2014 and 2016 with their cytopathology results.

Results: 498 of 12,381 patients had abnormal cytological findings (4.02\%). The rates of Atypical Squamous Cells of Undetermined Significance (ASC-US), Atypical Glandular Cells of Undetermined Significance (AG-US), Low Grade Squamous Intraepithelial Lesions (LGSIL) and High Grade Squamous Intraepithelial Lesions (HG-SIL) were found to be $1.9 \%$, $0.4 \%, 1 \%$ and $\% 0.1$, respectively. Atypical squamous cell cannot exclude HSIL (ASC-H) rate were found as $\% 0.4$. The rate of abnormal cytology in cervical intraepithelial lesions was 2.1. Positive predictive values of abnormal smear results were $21.7 \%$ for ASC-US, $41.9 \%$ for LGSIL, $100 \%$ for HGSIL, $12.5 \%$ for AGUS and $50 \%$ for ASC-H.

Conclusion: The Pap smear test is a cheap and easily applied screening test. Early diagnosis of cervix cancer can be made by routine Pap smear testing. The efficiency in clinical use of the cervical cytology screening test is determined by biopsy verification. As the ratio of epithelial cell abnormality is variable in different populations, the ASC (Atypical Squamous Cell) / SIL (Squamous Intraepithelial Lesion) is a more definite variable to be used for quality assurance.
\end{abstract}

Key words: Colposcopy, cytology, cervical smear

\section{Öz}

Amaç: Pap smear testi serviks kanserinin erken tanı ve tedavisinde çok önemli bir tarama yöntemidir. Bu çalışmanın amacı, smear testinde anormallik saptanan olguların yönetiminde kolposkopi ve patolojik incelemenin öneminin belirlenebilmesidir.

Gereç ve yöntemler: Bu çalıșmada 2014-2016 yılları arasında Düzce Atatürk Devlet Hastanesi Jinekoloji Polikliniği'ne başvuran 12.381 hastanın Bethesda sınıflamasına göre Pap Smear testi sonuçları ve kolposkopi eşliğinde alınan sitopatoloji sonuçları değerlendirilmiş ve karşıllaştırılmıștır.

Bulgular: 12.381 olgunun 498 'inde anormal sitolojik bulgular saptandı $(\% 4,02)$. Anormal sitolojilerin içerisinde önemi bilinmeyen hücreler (ASCUS) \% 1,9, Atipik Glanduler Hücreler (AGUS) \% 0,4, Düşük Dereceli Skuamöz İntraepitelyal Lezyon (LGSIL) \%1, Yüksek Dereceli İntraepitelyal Lezyon (HGSIL) \% 0,1, Atipik Skuamöz Hücrelerin Dışlanmadığı Grup (ASC-H) \% 0,4 olarak saptanırken, anormal sitolojilerin servikal intraepitelyal lezyonlara oranı 2,1 olarak saptandı. Pap Smear'de anormal sitolojik bulgu saptanan olguların pozitif öngörü değerleri ASCUS için \%21,7, LGSIL için \%41,9, HGSIL için \%100, AGUS için $\% 12,5$ ve ASC-H için $\% 50$ olarak hesaplandı.

Sonuç: Pap Smear testi, ucuz ve kolay bir yöntemdir. Serviks kanserinin erken tanısı Pap smear testi sayesinde mümkündür. Servikal sitolojinin klinik uygulamalarda güvenilir şekilde kullanımı ise biyopsi doğrulaması ile mümkündür. Farklı toplumlarda epitel hücre anomalisi oranı değişken olabildiği için atipik skuamöz hücre (ASH) / servikal skuamöz intraepitelyal lezyon (SIL) oranı kalite yöntemi açısından daha net bir veri olarak değerlendirilmektedir Anahtar kelimeler: Kolposkopi, sitoloji, servikal smear
${ }^{1}$ Department of Obstetrics and Gynecology, Sisli Hamidiye Etfal Research and Training Hospital, Istanbul, Turkey.

Şişli Hamidiye Etfal Eğitim ve Araştırma Hastanesi, Kadın Hastalıkları ve Doğum Kliniği,.İstanbul, Türkiye.

${ }^{2}$ Department of Obstetrics and Gynecology, Sakarya Research and Training Hospital, Sakarya, Turkey.

Sakarya Eğitim ve Araștırma Hastanesi, Kadın Hastalıkları ve Doğum Kliniği, İstanbul, Türkiye.

${ }^{3}$ Department of Obstetrics and Gynecology, Bayburt Government Hospital, Bayburt, Turkey.

Bayburt Devlet Hastanesi, Kadın Hastalıkları ve Doğum Kliniği, İstanbul, Türkiye.

Ethical approval: The study was approved by the local research ethics committee.

Etik Kurul: Çalışmanın lokal etik kurul onayı alınmıştır

Conflict of Interest: No conflict of interest was declared by the authors.

Çıkar Çatışması: Yazarlar çıkar çatışması bildirmemişlerdir.

Financial Disclosure: The authors declared that this case has received no financial support.

Finansal Destek: Yazarlar bu olgu için finansal destek almadıklarını beyan etmişlerdir.

Geliș Tarihi / Received

07.10 .2017

Kabul Tarihi / Accepted

26.10.2017

Yayın Tarihi / Published

01.12.2017

Sorumlu yazar / Corresponding author

Ozan Dogan

Adres/Address: Binbașı Refik Bey Sok. No:35/5, İstanbul, Türkiye.

Tel: +905055060720

E-posta: ozandogan02@hotmail.com

CC Copyright 2017 ACEM 


\section{Introduction}

Cancer is the second leading cause of death globally and is expected to be the first cause at year 2030 [1]. Cervical cancer is the overall second most common cancer in women and 50.000 new cases are reported yearly and 250.000 women die from this cause [2]. According to data verified from statistical analysis of 8 different cities of Turkey, by Republic of Turkey Ministry of Health Cancer Department reported at 2007 that cervical cancer is 10th cancer cause among Turkish women and the incidence is $4.76 / 100.000$. According to these numbers, the incidence of cervical cancer in Turkey is decreased by using the screening programs [3]. The natural behavior of cervical cancer is appropriate for screening programs, and the aim of the screening tests is to detect precancerous lesions early and avoid death. With pap-smear usage clinically, deaths caused by cervical cancer decreased dramatically (70\% per year) [4]. Although there were $6 \%-50 \%$ false negative rates, this test is still the most effective method for screening precancerous lesions [5, 6]. At the Unites States of America, approximately 50 million Pap smear tests are done and $5 \%$ of the cases need further examination. Colposcopy is the mostly preferable among further examination techniques. Colposcopic examination is used for clarifying cytological diagnosis; to determine the lesion's place and size, and for management of the therapy [7].

The aim of this study is to compare between management of abnormal cervical cytology by Bethesda Classification and correlation of histopathological diagnosis of cervical biopsy taken under colposcopic examination in our clinic.

\section{Materials and Methods}

In this study, 12,381 pap smears taken from patients referred to our gynecology clinic, between the years June 2014 and June 2016 were included retrospectively. The study protocol was approved by the Local Research Ethics Committee. All procedures performed in this study involving human participants were in accordance with the 1964 Helsinki declaration and its later amendments or comparable ethical standards.

Pap smear samples were dyed with Papanicolau method and evaluated using Bethesda system. The presence of endocervical cells was applied as the criteria for adequate cervical cytology. The pathological reports of the cases with atypical squamous cells of undetermined significance (ASC-US), atypical glandular cells of undetermined significance (AG-US), low grade squamous intraepithelial lesions (LG-SIL), high-grade squamous intraepithelial lesions (HG-SIL) and atypical squamous cell cannot exclude HSIL (ASC-H) were accepted as pathological [9]. 12.381 smear results were evaluated retrospectively. 498 of the cases which were referred as abnormal, colposopic examination has been made without any medical treatment or invasive procedure. During the colposcopic examination, by using 5\% acetic acid and Lugol solution, Schiller test was applied to the cervix and abnormal vein evaluation was performed under the green light. Cervical biopsy was performed for the patients with abnormal colposcopic examinations and histopathologic evaluation was made. Colposcopic results were grouped in normal, cervicitis, LGSIL, HGSIL, suspected adenoid structure and carcinoma. Cervical smear results and histopathological results were evaluated retrospectively. SPSS was used for the statistical analysis of data. Mean values and percentages of the descriptive data were calculated.

\section{Results}

Abnormal cytological findings detected in 498 of 12.381 smears $(4.02 \%)$. One hundred and forty one $(1.1 \%)$ cases were reported to have inadequate Pap smear samples for evaluation. The mean age of the patients was $40.4 \pm 9.8$ years (range 19-65 years). Abnormal cytology rate of all cases was $4.02 \%$. There were 242 ASC-US (48.5\%), 56 AG-US (11.2\%), 124 LG-SIL (24.8\%), 22 HG-SIL (4.4\%) and 54 ASC-H (10.8\%) cases among all abnormal cytologies. Colposcopy results of 454 of 498 patients with abnormal cytological findings were evaluated (Table 1). The ratio of abnormal cytologies to cervical intraepithelial lesions was 2.1 .

According to the results, 35 LG-SIL (17\%) and 8 HGSIL (4\%) were detected in colposcopic biopsy of 198 patients who were detected as ASC-US in the smear. In the colposcopic biopsies of 124 patients with LG-SIL, 34 LG-SIL (27\%) and 18 HG-SIL (14\%) were detected. Two LG-SIL (10\%) and 20 HGSIL $(90 \%)$ were detected in the colposcopic biopsy of 22 patients who had smear results as HG-SIL. Positive predictive values of cases with abnormal cytological results were $21.7 \%$ for ASCUS, $41.9 \%$ for LG-SIL, $100 \%$ for HG-SIL, $12.5 \%$ for AGUS and $50 \%$ for ASC-H (Table 2).

\section{Discussion}

The target population for screening tests is asymptomatic patients with no known disease. The aim of cancer screening is to decrease morbidity, mortality and the costs. Cervical malignant lesions have been extensively investigated for many years with cytological, histological and physical diagnostic methods. According to our current knowledge, it is assumed that cervical cancer does not appear suddenly, premalignant lesions vary from person to person, they become invasive at the end of a certain period of time, and even these premalignant lesions are regressed to a certain extent [8].

When the standard diagnosis criteria are used in Bethesda System, ASC-US cases should not be more than $5 \%$ of all cervico-vaginal smears. ASC-H is used for the lesions which are assumed as high grade intraepithelial lesion but does not show all HSIL criteria. It is a lesion with greater importance compared to ASC-US $[9,10]$. According to the new definitions, the ASC-US results are expected to be significantly reduced and the ASCUS / SIL ratio can be reduced to around 1 [11]. Five to ten percent of all cervico-vaginal smears which are evaluated with Bethesda system are diagnosed as ASC-US [12]. If the ASC-US diagnosis is more than this ratio, the inspection of the laboratory's quality control is required.

The clinical use of ASC-US with the Bethesda system depends on cytologists' training, better collection of specimens, and monitoring of laboratory diagnostic rates and quality control. The ASC-US / SIL ratio for quality control in cytology laboratories is an easy and useful measure. According to the authors of the Bethesda System, this ratio should be less than 3 [13]. The aim is to prevent unnecessary smear, colposcopy, biopsy repetition and anxiety by decreasing the diagnosis of ASC- US which means uncertainty. 
Table 1: Comparison between pap smear results and colposcopic biopsy.

\begin{tabular}{|c|c|c|c|c|c|c|c|}
\hline Smear & Normal & Cervicitis & LG-SIL & HG - SIL & $\begin{array}{c}\text { Suspected adenoid } \\
\text { structure }\end{array}$ & Carsinoma & Total \\
\hline ASCUS & $11(5.5)$ & $144(72.7)$ & 35 (17.6) & $8(4)$ & - & - & 198 \\
\hline LG-SIL & $3(2)$ & $69(55.6)$ & $34(27.4)$ & $18(14.5)$ & - & - & 124 \\
\hline HG-SIL & - & - & $2(10)$ & $20(90)$ & - & - & 22 \\
\hline AGUS & - & $49(83)$ & - & - & 7 (13) & - & 56 \\
\hline ASC-H & $15(27.7)$ & $12(22.2)$ & 27 (50) & - & - & - & 54 \\
\hline Total & 29 & 274 & 98 & 46 & 7 & - & 454 \\
\hline
\end{tabular}

ASC-US: Atypical Squamous Cells of Undetermined Significance, AG-US: Atypical Glandular Cells of Undetermined Significance, ASC-H: Atypical Squamous Cell cannot exclude HSIL,HG-SIL: High Grade Squamous Intraepithelial Lesions, LG-SIL: Low Grade Squamous Intraepithelial Lesions

In our study, abnormal cytology ratio among all cases was $4.02 \%$ and ASC-US ratio was $1.9 \%$. ASCUS $\backslash$ SIL ratio is detected as 2.1. These results are compatible with the literature. Cervix cancer is the second most common cancer in women. very year almost 50,000 new cases are reported and around 250,000 women lose their lives due to cervical cancer. Mean age of the diagnosis is 51, and the incidence peaks at the ages of 35 59 and 60-64 years [14]. Early sexual intercourse, multiple sexual partner, low socioeconomic level, smoking, vitamin A deficiency and human papilloma virus are known risk factors $[15,16]$. Increasing numbers of routine pap smear scans in developing countries have reduced the incidence of deaths due to invasive cervical cancer $[17,18]$. For that reason, prevention of cervix cancer and early treatment depends on the regular screening tests in appropriate age groups and detection of the patients with risk factors [19].

Cervical cancer screening should be done once a year regularly since three years after the first sexual intercourse or 21 years of age. Pap smear screening should be done once a year under the age of 30, and once in 2-3 years if there are 3 negative smear result after the age of $30[20,21]$.

Studies proved that considering the screening of cervical pathologies, conventional cytology has $30-87 \%$ of sensitivity and $86-100 \%$ of specificity while liquid based cytology has $61-95 \%$ of sensitivity and $78-82 \%$ of specificity $[22,23]$. Çelik et al. [24] compared the conventional and liquidbased cytologies evaluating 8,100 smear results, and the study does not show any statistically significant difference between these techniques on identifying atypical cells or other epithelial cell abnormalities. Conventional cervical cytology is preferred in our clinic.

Table 2. Positive predictive values of the cases identified with abnormal cytological findings on Pap smear.

\begin{tabular}{lc} 
Diagnosis & Percentage $(\%)$ \\
\hline ASCUS & 21.7 \\
LG-SIL & 41.9 \\
HG-SIL & 100 \\
AGUS & 12.5 \\
ASC-H & 50
\end{tabular}

ASC-US: Atypical Squamous Cells of Undetermined Significance, LG-SIL: Low Grade Squamous Intraepithelial Lesions, HG-SIL: High Grade Squamous Intraepithelial Lesions, AG-US: Atypical Glandular Cells of Undetermined Significance, ASC-H: Atypical Squamous Cell cannot exclude HSIL

Atılgan et al. [25] identified 1.9\% ASCUS, 0.1\% ASC$\mathrm{H}, 0.2 \%$ AG-US, $0.5 \%$ LGSIL and $0.1 \%$ HGSIL in their research in which 32,026 smear results are evaluated. Total rate was specified as $2.8 \%$ in all of the smear results. Keskin et al. [26] examined 18,303 smear results, and found that the rate of HGSIL as $4.9 \%$ and the rate of benign results as $74 \%$ in 101 patients in whom ASCUS diagnosed following the biopsy outcomes. HGSIL was observed in $12.5 \%$ of 48 patients diagnosed with LGSIL, and HGSIL was observed in $75 \%$ of 8 patients diagnosed with HGSIL.
Turkmen et al. [4] determined 2.7\% ASCUS, 0.2\% ASC-H, $1.1 \%$ LGSIL, $0.2 \%$ HGSIL and $0.1 \%$ AG-US in their research which evaluated 13,610 pap smear results. They found the rate of ASC\SIL as 2.12. In our research, 12,381 pap smear results were investigated, abnormal epithelial cells were identified in 498 results, and colposcopy outcomes were evaluated in 454 of them. Abnormal cytology rate was found as $4.02 \%$. In the abnormal cytologies, ASC-US was identified as $1.9 \%$, AG-US as $0.4 \%$, LG-SIL as $1 \%$, HG-SIL as $0.1 \%$ and ASC-H as $0.4 \%$ while the ratio of abnormal cytologies to cervical intraepithelial lesions was found as 2.1. Positive predictive values of the cases with abnormal cytological outcomes in the pap smear were $21.7 \%$ for ASCUS, $41.9 \%$ for LGSIL, $100 \%$ for HGSIL, $12.5 \%$ for AGUS, and 50\% for ASC$\mathrm{H}$. These determinations in our research show similarity between the literature findings.

To conclude, Pap smear test is a low-priced and manageable method. Early diagnosis of cervical cancer is possible with pap smear test. However, safe usage of cervical cytology in the clinical practice is available with biopsy confirmation. The ratio of ASH/SIL is considered as clearer data from the aspect of quality management because of the variability in the ratio of epithelial cell abnormalities. Significance of Pap smear test, regular check up, healthy lifestyle should be disclosed to societies for the early diagnosis of cervical cancer.

\section{References}

1. Smith RA, Cokkinides V, Brooks D, Saslow D, Shah M, Brawley OW Cancer screening in the United States, 2011: A review of current American Cancer Society guidelines and issues in cancer screening. CA Cancer J Clin 2011; 61: 8-30.

2. Jemal A, Bray F, Center M, Ferlay J, Ward E, Forman D. Global cancer statistics. CA Cancer J Clin 2011; 61: 69-90.

3. Özer H, Tuncer E, Çiftçi A, Keser H, Aker H, Elagöz, S, et al. Distribution of cytological diagnoses in cervical smears with epithelial cell abnormality and cyto-histopathological correlation. Cumhuriyet Med J 2012; 34: 319-24.

4. Türkmen İ., Başsüllü N, Korkmaz P, Günenç B, Baykal C. Patients with Epithelial Cell Abnormality in PAP Smears: Correlation of Results with Follow-Up Smears and Cervical Biopsies. Turk Patoloji Derg 2013, 29:179-84.

5. Saslow D, Runowicz CD, Solomon D, Moscicki AB, Smith RA, Eyre $\mathrm{HJ}$, et al. American Cancer Society guideline for the early detection of cervical neoplasia and cancer. CA Cancer J Clin 2002; 52: 342-62.

6. Kuo DY, Goldberg GL. Screening of cervical cancer: where do we go from here? Cancer Invest 2003; 21: 157-61.

7. Benedet J, Matisic J, Bertrand M. An analysis of 84,244 patients from the British Columbia cytology-colposcopy program. Gynecol Oncol 2004; 92: 127-34.

8. Destegül E, Gençdal S, Ekmekçi E, Aydoğmuş H, Özdemir O. Evaluation of cervicovaginal smear results at postmenopausal period Adv Mod Oncol Res 2016; 2: 45-9.

9. Zweizig S, Noller K, Reale F, Collis S, Resseguie L. Neoplasia associated with atypical glandular cells of undetermined significance on cervical cytology. Gynecol Oncol 1997; 65: 314-8.

10. Güçkan R.,Kılınç Ç ,Gözdemir E, Gürçağlar A, Nergiz Ö. Prevalence and distribution of high-risk human papillomavirus in Amasya region, Turkey. Biomed Res 2016; 27: 769-72.

11. Human papillomavirus testing for triage of women with cytological evidence of low-grade squamous intraepithelial lesions: baseline data 
from a randomized trial. The Atypical Squamous Cells of Undetermined Significance/ Low-Grade Squamous Intraepithelial Lesions Triage Study (ALTS) Group. J Natl Cancer Inst 2000; 92: 397-402.

12. ACOG Practice Bulletin on Clinical Management Guidelines for Obstetricians-Gynecologists. Management of abnormal cervical cytology and histology. In: ACOG Women's Health Care Physician's Compendium of Selected Publications, practice bulletinnumber 66 , September 2005.Washington (DC): ACOG Distribution Center, 2006; 603-22.

13. Boztosun A, Mutlu A, Özer H, Aker H, Yank1 A. Serviko vajinal smearde epitelyal hücre anomalisi saptanan hastaların kolposkopik biyopsi sonuçlarının değerlendirilmesi. TürkJinekolojik Onkoloji Dergisi 2012; 1: 13-9.

14. Isaoglu U, Yilmaz M, Delibas İ, Bilici A, Kabalar M. Evaluation of 37,438 consecutive cervical smear results in the Turkish population. Arch Med Sci 2015; 11: 402-5.

15. Turkistanlı EC, Sogukpinar N, Saydam BK, Aydemir G. Cervical cancer prevention and early detection - the role of nurses and midwives. Acian Pac J Cancer Prev 2003; 4: 15-21.

16. Soler ME, Gaffikin L, Blumenthal PD. Cervical cancer screening in developing countries. Prim Care Update Ob Gyns 2000; 7: 118-23.

17. Waxman AG. Guidelines for cervical cancer screening, history and scientific rationale. Clin Obstet Gynecol 2005; 48: 77-97.

18. Saraiya UB. Preventable but not prevented: the reality of cervical cancer. J Obstet Gynecol Res 2003; 29: 351-9.

19. Seven A, Koçak C, Yüksel K, Kucur S, Gözükara İ. The evaluation of cervical pap-smear results of the patients who admitted to Obstetrics and Gynecology Clinic of Dumlupinar University Kutahya Evliya Celebi Training and Research Hospital. Turk J Clin Lab 2015; 7: 1-4.

20. American College of Obstetricians and Gynecologists. ACOG practice bulletin. Cervical Cytology screening. Number 45, August 2003. Int J Gynaecol Obstet 2003; 83: 237-47.

21. Gokaslan H, Uyar EE. Screening cervical cancer with Pap smear. Turk Aile Hek Derg 2004; 8: 105-10.

22. Biedka M, Makarewicz R, Kopczyńska E, Marszałek A, Goralewska A, Kardymowicz H. Angiogenesis and lymphangiogenesis as prognostic factors after therapy in patients with cervical cancer. Contemp Oncol (Pozn) 2012; 16: 6-11.

23. Belinson J, Qiao YL, Pretorius R, Zhang WH, Elson P, Li L, et al. Shanxi province cervical cancer screening study: a cross-sectional comparative trial of multiple techniques to detect cervical neoplasia. Gynecol Oncol 2001; 83: 439-44.

24. Celik C, Gezginc K, Toy H, Findik S, Yilmaz O. A comparison of liquid-based cytology with conventional cytology. Int J Gynecol Obstet 2008; 100: 163-6.

25. Atilgan R, Celik A, Boztosun A, Ilter E, Yalta T, Ozercan R. Evaluation of cervical cytological abnormalities in Turkish population. Indian J Pathol Microbiol 2012; 55: 52-5.

26. Keskin HL, Seçen Eİ, Taş E, Kaya S, Avşar AF. Servikal smear sitolojisi ile kolposkopi eşliğinde servikal biyopsi korelasyonu. Türk Jinekolojik Onkoloji Dergisi 2011; 3: 71-5. 